\title{
Anti-CD52 Monoclonal Antibody ALLO-647
}

National Cancer Institute

\section{Source}

National Cancer Institute. Anti-CD52 Monoclonal Antibody ALLO-647. NCI Thesaurus.

Code C160787.

A monoclonal antibody directed ag ainst the cell surface glycoprotein CD52 (CAMPATH-1 antigen; Cambridge pathology 1 antigen), with potential immunodepleting activity. Upon administration, anti-CD52 monoclonal antibody ALLO-647 selectively targets and binds to CD52, thereby triggering a host immune response that results in the lysis of CD52-

positive lymphocytes. This leads to immunodepletion and may prevent graft-versus-host disease (GvHD). CD52 is a glycoprotein expressed on the surface of many immune cells, including essentially all B-and T-lymphocytes. 